\title{
Effect of fibronectin on early embryo development in cows
}

\author{
R. C. Larson*, G. G. Ignotz and W. B. Currie $\dagger$ \\ Department of Animal Science, Cornell University, Ithaca, NY 14853, USA
}

\begin{abstract}
Summary. Two-cell bovine embryos produced in vitro were cultured in serum-free medium containing the soluble glycoprotein fibronectin $\left(50 \mu \mathrm{g} \mathrm{ml}^{-1}\right)$ to study the function of the extracellular matrix in early development. Some of the embryos $(48 / 164,29 \cdot 3 \%)$, developed beyond the 16-cell stage compared with none of the 179 controls. Fibronectin at lower $\left(5 \mu \mathrm{g} \mathrm{ml}^{-1}\right)$ or higher $\left(300 \mu \mathrm{g} \mathrm{ml}^{-1}\right)$ concentrations did not promote embryo development $(0 / 89$ and $0 / 82$, respectively). Indirect immunofluorescence demonstrated the presence of both fibronectin and its receptor on the surface of eight-cell embryo blastomeres, and biotinylated fibronectin demonstrated that exogenous fibronectin could cross the zona pellucida. These results, demonstrating the successful culture of bovine embryos in serum-free medium, support the hypothesis that the extracellular matrix, specifically fibronectin, plays a role in early development of bovine embryos.
\end{abstract}

Key'urds: fibronectin; embryos; cow

\section{Introduction}

Early bovine embryos cultured in vitro arrest development during the eight- to 16-cell stage (Thibault, 1966, Camous et al., 1984). This 'block' to development may represent the failure of initiation of expression of the embryonic genome because the embryo becomes transcriptionally active either shortly before or during this time (Barnes, 1988) and undergoes major changes in patterns of protein synthesis (Frei et al., 1989). We have observed (unpublished) that the individual blastomeres of blocked embryos, produced in vitro from abattoir material by the methods described by Parrish et al. (1988), exhibit abnormal and irregular morphology compared with the more spherical, uniform appearance of embryos derived in vivo (Hamilton \& Laing, 1946).

Numerous other cell types are known to display similar aberrations when cultured in vitro. Culturing cells on an extracellular matrix may partially ameliorate these abnormalities by stimulating transcription and translation (Bissell et al., 1988), promoting mitosis (Gospodarowicz et al., 1982), and changing the morphology of the cells to that more representative of the situation in vivo (Watt, 1986).

Among the several components of the extracellular matrix, the soluble glycoprotein fibronectin, found on cells and in blood (Yamada, 1982), could serve as a maternal factor contributing to early development because it is a likely component of oviductal fluid, an exudate of serum (Leese, 1988). Further evidence for a role for fibronectin includes the finding that fibronectin is present on the surface of early murine embryos (Yokkaichiya et al., 1988) and the selective sequestration of large glycoproteins $\left(M_{\mathrm{r}}\right.$ fibronectin $\left.=220\right)$ on the surface of murine blastomeres during early development (Kapur \& Johnson, 1986). Additionally, Xenopus embryos, which develop externally, synthesize fibronectin (Lee et al., 1984), and individual blastomeres of murine embryos can grow and proliferate on a fibronectin matrix (Wilton \& Trounson, 1989).

*Present address: AFRC Institute of Animal Physiology and Genetics Research, Babraham, Cambridge CB2 4AT UK.

$\dagger$ Reprint requests. 
In this experiment, the hypothesis that fibronectin affects early development was tested by adding fibronectin to serum-free cultures of two-cell bovine embryos produced in vitro and observing its effect on development. Fluorescent techniques were used to investigate the presence of fibronectin and the fibronectin receptor on the blastomere membrane, and to determine whether fibronectin can cross the zona pellucida.

\section{Materials and Methods}

\section{Embryo culture}

Embryos were produced by the methods described by Ball et al. (1983) and Parrish et al. $(1985,1988)$ using ovaries collected at an abattoir (Taylor Packing Company, Wyalusing, PA). Oocytes aspirated from these ovaries were matured and fertilized in vitro using fresh, heparin-treated spermatozoa. About the time of the first cleavage division ( $24 \mathrm{~h}$ after the addition of spermatozoa to the oocytes) cumulus cells were removed by vortexing and the embryos were washed and allocated randomly to treatments. The basal medium used for subsequent embryo culture was cholesterol-free $\mathbf{B}_{2}$ (Menezo et al., 1984), custom prepared by Sigma Chemical Company (St Louis, MO) and adjusted

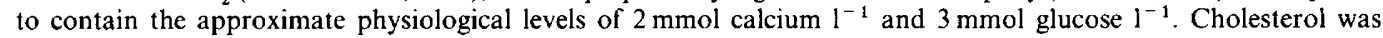
omitted because it would not readily pass through the filter apparatus used for sterilization.

\section{Experiment 1}

This experiment assessed development of embryos cultured in the presence of fibronectin. Bovine serum fibronectin (Sigma) was dissolved in sterile water and twice dialysed ( $25 \mathrm{kDa}$, MWCO, Spectrapor, Spectrum, Los Angeles, CA) against a 200-fold excess of medium. This preparation was electrophoretically homogeneous when examined by sodium dodecyl sulfate polyacrylamide gel electrophoresis (SDS-PAGE) and silver staining. Fibronectin was then added to the culture medium to a final concentration of $5,50 \mathrm{or} 300 \mu \mathrm{g} \mathrm{ml}^{-1}$. Cumulus-free embryos (groups of five) were cultured in $500 \mu \mathrm{l}$ of medium at $39^{\circ} \mathrm{C}$ in an atmosphere of $5 \% \mathrm{CO}_{2}$ in air. Embryos were observed daily for 10 days after fertilization using phase contrast microscopy to assess and record development beyond the 16-cell stage, morula formation and blastulation.

\section{Experiment 2}

The second experiment evaluated the effect of Gly-Arg-Gly-Asp-Ser (GRGDS) (Sigma) on the action of fibronectin. This pentapepide competitively inhibits the binding of fibronectin to its receptor (Pierschbacher \& Ruoslahti, $1984 a, b)$. Treatments were arranged in a $2 \times 2$ factorial design; the main factors were the addition to the medium of $50 \mu \mathrm{g}$ fibronectin $\mathrm{ml}^{-1}$ or $50 \mu \mathrm{g}$ GRGDS ml $\mathrm{H}^{-1}$. Embryos were treated from the two-cell stage and assessed as described above.

\section{Statistical analysis}

In the first experiments, an experimental unit was five embryos cultured together in $500 \mu \mathrm{l}$ of medium. Results were tabulated as the number of embryos in each experimental unit that developed to a specific stage divided by the total number of embryos in each unit that completed at least one cleavage division. This method excluded from the analysis oocytes that were either not fertilized or could not undergo a single cleavage division.

Experiments used a randomized complete block design; each block consisted of oocytes that were harvested, fertilized and cultured from one collection of ovaries. Within each block an average of 43 experimental units (215 oocytes) were assigned randomly to treatments. When appropriate, comparisons were made between treatments using single degree of freedom orthogonal contrasts. In cases when comparisons were made between treatments and controls when the mean and variance of the control group were both zero, a standard error, calculated using the within block, within treatment error, was used to test the null hypothesis that the mean of a particular treatment was equal to zero.

\section{Experiment 3}

This experiment attempted to detect fibronectin and the fibronectin receptor on the surface of the blastomeres quantitatively, using the method of indirect immunofluorescence described by Quaroni (1985). Modifications to this technique included removal of the zona with acid Tyrode's solution (Bornslaeger \& Schultz, 1985) followed by direct fixation in $4 \%$ paraformaldehyde with neutralization of unreacted aldehydes with $100 \mathrm{mmol}_{\text {glycine }} 1^{-1}$ in phosphatebuffered saline (PBS). After counterstaining with $0.1 \%$ Evans Blue, embryos were mounted on slides with glycerol: PBS $(9: 1 \mathrm{v} / \mathrm{v})$. PBS, containing $2 \%$ non-immune goat serum and $0.01 \%$ Triton $\mathrm{X}-100$, was used for all dilutions and washings. 
Primary antibodies were purchased from Telios Pharmaceuticals (San Diego, CA), and included rabbit anti-bovine fibronectin (lot no. 8B0037, Ruoslahti et al., 1982), used at a dilution of 1:50, and rabbit antihuman fibronectin receptor (lot no. 9A0190, Cardarelli \& Pierschbacher, 1987), used at a dilution of 1:10. The secondary antibody was fluorescein-conjugated goat anti-rabbit IgG (lot no. 17F-8838, Sigma), which fluoresced yellow compared with the organge-red colour of the counterstain when observed and photographed with a Nikon Optiphot microscope equipped with an epifluorescence attachment. Black and white negatives were prepared from coloured slides using Kodak Technical Pan film and a green filter to reduce the orange-red background of the Evans Blue.

Treatment groups in this experiment included embryos that had been cultured for $48 \mathrm{~h}$ in either the presence or absence of fibronectin as described above. Embryos in each treatment group were evaluated using antibodies against either fibronectin or its receptor. An additional control was made using embryos taken from identical treatments but in which a 1:1000 dilution of non-immune rabbit serum was substituted for specific primary antibody.

\section{Experiment 4}

The final experiment investigated accessibility of fibronectin to the blastomeres through the zona. Embryos were incubated as above in the presence of native or biotinylated fibronectin. Biotinylated fibronectin was prepared by a method similar to that described by Hnatowich et al. (1987). Bovine plasma fibronectin (1 mg) was reacted with $20 \mu \mathrm{g}$ of NHS-LC-biotin (Pierce, Rockford, IL), allowing for an approximate molar ratio of 8 biotins per fibronectin monomer. Unreacted ligand was removed by diafiltration on a $10 \mathrm{kDa}$ MWCO centrifugal membrane. After incubation with fibronectin for $48 \mathrm{~h}$, embryos that had developed to the eight-cell stage were harvested. Zonae were removed with acid Tyrode's solution to eliminate the considerable amount of biotinylated fibronectin that appeared to be associated with these structures. The embryos were then incubated for $30 \mathrm{~min}$ in the presence of fluoresceinconjugated avidin (Pierce) with $0.02 \%$ sodium azide, washed three times with PBS-azide, counterstained with $0 \cdot 1 \%$ Evans Blue, washed twice more, mounted on a glass slide with glycerol:PBS $(9: 1 \mathrm{v} / \mathrm{v})$ and observed for fluorescence. The two treatment groups included embryos incubated for $48 \mathrm{~h}$ in the presence of biotinylated or native fibronectin. Results were recorded as in the previous experiment.

\section{Statistical analysis}

In Expts 3 and 4, the embryos were qualitatively evaluated for the presence or absence of a yellow fluorescent signal, and treatment differences were assessed with $\chi^{2}$ analysis. At least six eight-cell embryos were analysed from each treatment group.

\section{Results}

\section{Experiment 1}

Of the embryos cultured in the presence of fibronectin $\left(50 \mu \mathrm{g} \mathrm{ml}^{-1}\right), 29 \cdot 3 \%(48 / 164)$ developed beyond the 16-cell compared with $0 \%$ of the controls $(0 / 179)(P<0 \cdot 01$, Table 1$)$. The proportion of embryos treated with $50 \mu \mathrm{g}$ fibronectin $\mathrm{ml}^{-1}$ that developed to the eight- to 16-cell stage averaged $40.9 \%$, and was not different from the proportion of control embryos developing to the same cell stage $(31 \cdot 2 \%, P<0 \cdot 12)$. Of the 48 embryos that developed beyond the 16-cell stage, 11 ( $6.7 \%$ of the 164 that initially cleaved) developed into blastocysts; four of these hatched in culture. An additional five blastocysts expanded, but the blastocoel collapsed before hatching occurred.

None of the embryos treated with either $5 \mu \mathrm{g}$ or $300 \mu \mathrm{g}$ fibronectin $\mathrm{ml}^{-1}$ developed beyond the 16-cell stage (Table 1). Five of the embryos cultured with $300 \mu \mathrm{g}$ fibronectin $\mathrm{ml}^{-1}$ appeared to have accumulated translucent material that occupied more than half of the volume within the zona. In these embryos, it was not possible to distinguish the cellular boundaries of individual blastomeres when using phase contrast microscopy.

Analysis of the rate of early development of these embryos showed that of those that were competent to develop to the eight-cell stage, most $(87 \cdot 4 \%)$ had completed the third cleavage division by three days after fertilization; a few (7.6\%) developed to the eight-cell stage within two days. Of 48 embryos that reached the 16-cell stage, $81 \cdot 2 \%(39 / 48)$ had done so by the fourth day after fertilization and the remainder did so on the fifth day. During the fifth and sixth days of culture, the blastomeres located on the periphery of developing embryos showed clearly visible spherical outlines, indicating an absence of cell flattening. These embryos began to develop into 
Table 1. Development of two-cell bovine embryos produced in vitro cultured in the presence of 5,50 or $300 \mu \mathrm{g}$ fibronectin $\mathrm{ml}^{-1}$

\begin{tabular}{lcccc}
\hline & $\begin{array}{c}\text { Number of } \\
\text { embryos } \\
\text { Teveloping to } \\
\text { the eight- to } \\
\text { embryos per } \\
\text { treatment }\end{array}$ & $\begin{array}{c}\text { Number of } \\
\text { embryos } \\
\text { developing } \\
\text { beyond the } \\
\text { 16-cell stage }\end{array}$ & $\begin{array}{c}\text { Number of } \\
\text { embryos } \\
\text { developing to } \\
\text { blastocysts }\end{array}$ \\
\hline Control & 179 & 62 & 0 & 0 \\
$\begin{array}{l}\text { Fibronectin } \\
\left(5 \mu \mathrm{g} \mathrm{ml}^{-1}\right)\end{array}$ & 89 & 25 & 0 & 0 \\
$\begin{array}{l}\text { Fibronectin } \\
\left(50 \mu \mathrm{g} \mathrm{ml}^{-1}\right)\end{array}$ & 164 & 71 & 48 & 11 \\
$\begin{array}{l}\text { Fibronectin } \\
\left(300 \mu \mathrm{g} \mathrm{ml}^{-1}\right)\end{array}$ & 82 & 34 & 0 & 0 \\
\hline
\end{tabular}

blastulae on day 6 and 7 of culture without first forming a typical tightly compacted morula. All the embryos that hatched in culture did so on day 10 after fertilization.

In a companion experiment, six embryos produced in this way were nonsurgically transferred to recipient heifers. Three heifers received two embryos each. None of the animals became pregnant as assessed by subsequent occurrence of oestrus, but this occurred after abnormally long intervals in two of the animals ( 28 and 34 days).

\section{Experiment 2}

The specificity of the fibronectin effect (Expt 1) was examined using the GRDGS peptide. On the basis of other studies (Pierschbacher \& Ruoslahti, 1984a, b), it was expected that GRGDS would abolish any stimulatory effect by competing for binding with the cellular receptor; there was no precedent for anticipating any stimulatory effect of GRGDS itself. The results obtained (Table 2) demonstrated a unique GRGDS action that was clearly different from either the control or fibronectin treatment. As before, none of the control embryos developed to the 16-cell stage. Fibronectin alone promoted development beyond the 16-cell stage in $30.8 \%$ of the two-cell embryos, some of which had formed a blastula (9.0\%). GRGDS by itself had an effect on a similar proportion of two-cell embryos $(38.6 \%)$, although the effect was to promote an obvious increase in degree of compaction and a complete blockade of blastocyst formation. Subjective comparisons indicated that on the eighth day of culture the GRGDS-treated embryos had less blastomere fragmentation and retained a more uniformly coloured cytoplasm than did control embryos or those known to be dead.

\section{Experiment 3}

Visual appraisal detected no apparent difference between the strength of the fluorescent signal of fibronectin-treated or control eight-cell embryos when examined using rabbit anti-bovine fibronectin $\left(\chi^{2}<0 \cdot 70\right)$. In the group treated with fibronectin, seven of eight embryos gave a positive signal, yet all eight embryos cultured without addition of fibronectin gave a positive signal. None of the six embryos from either treatment group fluoresced when non-immune serum was substituted for primary antibody $\left(\chi^{2}<0 \cdot 01\right.$, Fig. 1$)$.

The intensity of fluorescence using rabbit anti-fibronectin receptor antibodies was less than that obtained with antibodies directed against bovine fibronectin but was clearly greater than that in embryos evaluated using non-immune rabbit serum $\left(\chi^{2}<0 \cdot 01\right.$, Fig. 2$)$. Addition of fibronectin to the medium used to culture embryos did not affect subsequent immunofluorescent detection of the 
Table 2. The effect of fibronectin and the pentapeptide Gly-Arg-Gly-Asp-Ser (GRGDS) on the development of two-cell bovine embryos in vitro

\begin{tabular}{|c|c|c|c|c|}
\hline Treatment & $\begin{array}{l}\text { Total two-cell } \\
\text { embryos }\end{array}$ & $\begin{array}{l}\text { Number of } \\
\text { embryos } \\
\text { developing to } \\
\text { the eight- to } \\
\text { 16-cell stage }\end{array}$ & $\begin{array}{l}\text { Number of } \\
\text { embryos } \\
\text { developing } \\
\text { beyond the } \\
\text { 16-cell stage* }\end{array}$ & $\begin{array}{l}\text { Number of } \\
\text { embryos } \\
\text { developing to } \\
\text { blastocysts }\end{array}$ \\
\hline Control & 84 & 34 & 0 & 0 \\
\hline $\begin{array}{l}\text { Fibronectin } \\
\left(50 \mu \mathrm{g} \mathrm{ml}^{-1}\right)\end{array}$ & 78 & 35 & 24 & 7 \\
\hline $\begin{array}{l}\text { GRGDS } \\
\left(50 \mu \mathrm{g} \mathrm{ml}^{-1}\right)\end{array}$ & 171 & 78 & 66 & 0 \\
\hline $\begin{array}{l}\text { Fibronectin }\left(50 \mu \mathrm{g} \mathrm{ml}^{-1}\right) \\
\text { plus GRGDS }\left(50 \mu \mathrm{g} \mathrm{ml}^{-1}\right)\end{array}$ & 165 & 68 & 47 & 0 \\
\hline
\end{tabular}

*Observation with phase contrast microscopy indicated that during this stage of development the degree of compaction was greater among embryos incubated with GRDGS than in embryos exposed to fibronectin alone.

(a)

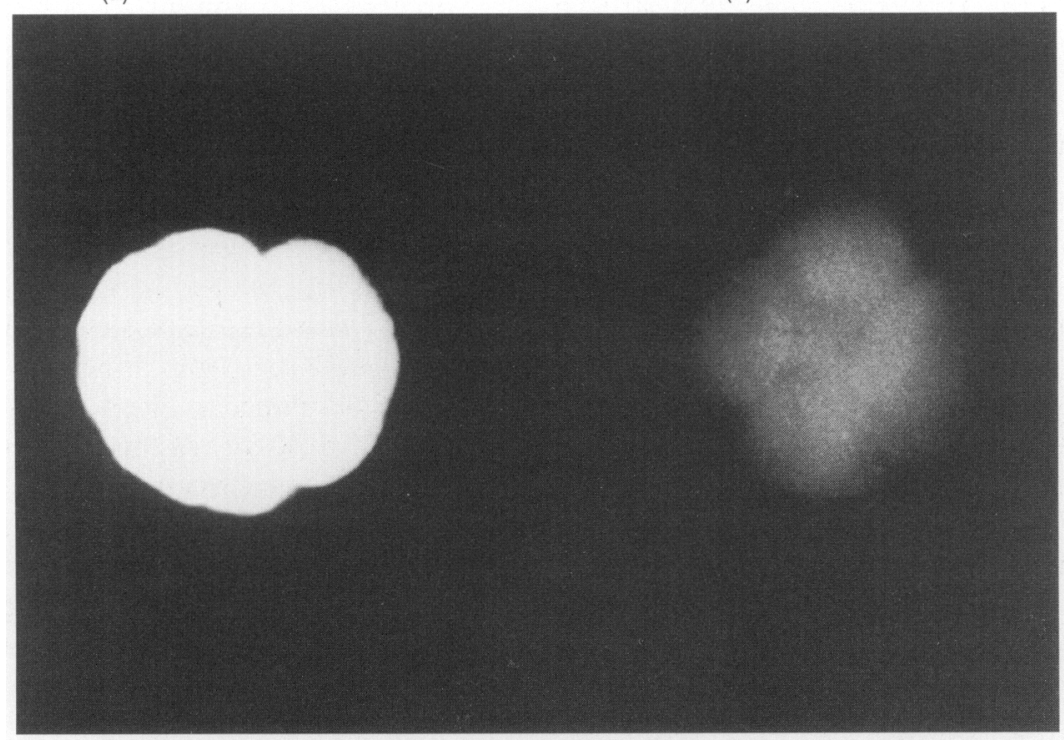

Fig. 1. Indirect immunofluorescence using (a) rabbit anti-bovine fibronectin as the primary antibody or (b) non-immune rabbit serum. No difference was detected between fibronectintreated and control embryos stained with the primary antibodies.

fibronectin receptor $\left(\chi^{2}<0.42\right)$; seven of nine incubated with fibronectin were positive as were six of eight control embryos.

\section{Experiment 4}

All six of the embryos that had been exposed to biotinylated fibronectin during a $48 \mathrm{~h}$ incubation bound fluorescein-conjugated avidin and fluoresced strongly (Fig. 3). There was no fluorescence in embryos incubated with native fibronectin $\left(\chi^{2}<0.01\right)$. 


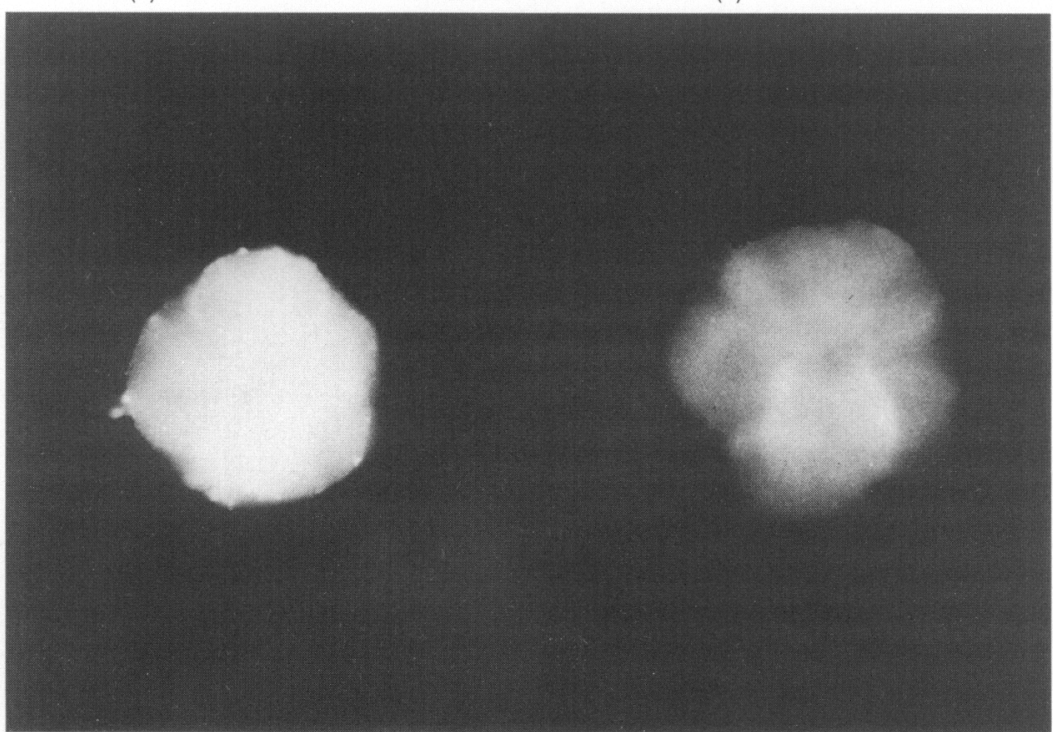

Fig. 2. Indirect immunofluorescence indicated the presence of the fibronectin receptor on the blastomere surlace. The primary antibody in (a) was rabbit anti-human fibronectin receptor: a non-immune rabbit serum was used in (b).

(a)

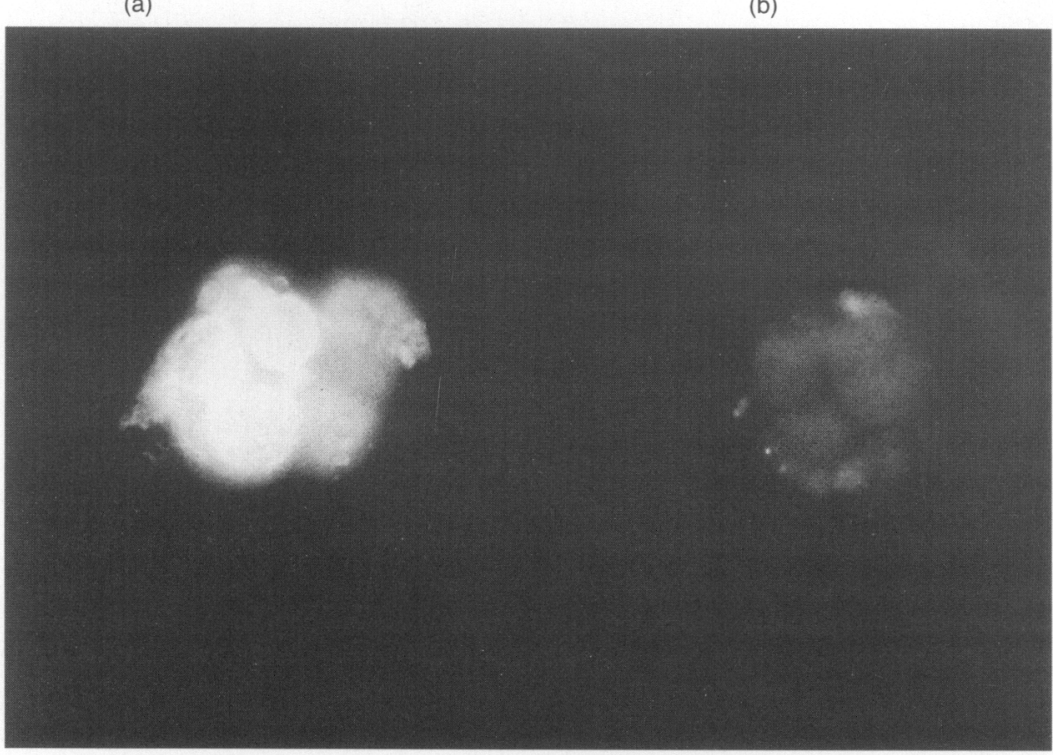

Fig. 3. A strong fluoresent signal was detected on the surface of embryos incubated with biotinylated fibronectin (a) for $48 \mathrm{~h}$ before zona removal followed by fibronectin-conjugated avidin. Control embryos (b) were incubated with native fibronectin. The results show that fibronectin can cross the zona pellucida. 
Fluorescence in the embryos treated with biotinylated fibronectin was not uniform across all blastomeres. In two cases, only six of the eight blastomeres were labelled. Within a given blastomere, however, the fluorescence appeared to be uniformly distributed over the surface of the cell.

\section{Discussion}

These experiments demonstrate that the addition of fibronectin to a basal, serum-free medium used to culture very early bovine embryos promotes development beyond the eight- to 16-cell stage. The proportion of embryos that developed beyond the eight- to 16-cell stage in this study $(29 \cdot 3 \%)$ is comparable to the proportion developing to an equivalent stage in other in vitro studies $(29.2 \%$, Eyestone \& First, 1989) which use either coculture with oviductal cell monolayers or medium conditioned in the presence of oviductal cells. Beyond these earliest events, however, only $6.7 \%$ of cleaved embryos developed into blastocysts whereas $22.1 \%$ of embryos developed to the blastocyst stage when cultured with oviductal monolayers or in conditioned medium (Eyestone \& First, 1989). These observations indicate that fibronectin alone is as effective as co-culture in mimicking events that normally occur in the oviduct, but much less effective in promoting developmental events that occur in the uterus, including compaction and blastulation (Hamilton \& Laing, 1946, Betteridge \& Fléchon, 1988).

The developmental rate of embryos that were successfully grown with fibronectin appears to be delayed only slightly compared with the expected rate in vivo (Hamilton \& Laing, 1946; Thibault, 1966), with blastocyst formation occurring on day 6 or 7 after fertilization and hatching on day 10. These embryos were considered to be of very low quality when visually appraised by experienced embryo transfer technicians, and, in a strictly limited test involving transfer to only three heifers, pregnancies did not result. Two of the three animals demonstrated abnormally long oestrous cycles after transfer, which may indicate some degree of embryo development that can achieve maternal recognition of pregnancy and delay of luteolysis yet is insufficient to develop into a sustainable pregnancy. It is therefore likely that embryos produced by incubation with fibronectin do not have developmental potential equivalent to embryos produced by co-culture or incubation with conditioned medium.

The pentapeptide GRGDS, a competitive inhibitor of fibronectin binding (Pierschbacher \& Ruoslahti, 1984a, b), specifically blocked the fibronectin effect on blastocyst formation. An unexpected result showed that GRGDS promoted compaction. GRGDS-dependent compaction has been observed in isolated segmental plate cells from chick embryos (Lash et al., 1987). Compaction, both in embryos and the segmental plate, results from activation of the cell adhesion molecule uvomorulin, a transmembrane protein the adhesive properties of which are derived from interactions with identical molecules on adjacent cells (Edelman, 1988). Uvomorulin, which is present before compaction and synthesized as early as the two-cell stage in mouse embryos (Vestweber et al., 1987), may be activated by GRGDS (Lash et al., 1987).

The indirect immunofluorescent studies demonstrated that fibronectin was present on the blastomere surface regardless of whether fibronectin was included in the culture medium. This observation agrees with those of the mouse embryo (Yokkaichiya et al., 1988) and indicates that fibronectin is an endogenous extracellular matrix component on the blastomere surface of developing bovine embryos. These observations also suggest that the fibronectin receptor is present because of the receptor-related fluorescent signal and because receptor binding is required for fibronectin to form the detergent-insoluble, cytocortical fibrils (McDonald, 1988) observed when using an anti-fibronectin antibody for immunofluorescence. Finally, the use of biotinylated fibronectin demonstrated that exogenous fibronectin can reach the blastomeres of the zona-intact, early embryo. This is consistent with the characterization of the zona as a porous structure (Wassarman, 1990) that allows the passage of viruses and other large particles including ferritin $\left(M_{\mathrm{r}}=500\right)$. 
This study showed that an appropriate concentration of added fibronectin promoted proliferation of the bovine blastomeres. The specificity of the overall fibronectin effect is apparent because it can be blocked with the GRGDS peptide. Fibronectin, either endogenous or added, was found to be present on the surface of the eight-cell embryo and labelled fibronectin crossed the zona pellucida.

We thank A. Quaroni for supplying technical assistance and equipment necessary for immunofluorescence. This study was funded in part by the New York State Agricultural Experiment Station.

\section{References}

Ball, G.D., Leifried, M.L., Lenz, R.W., Ax, R.L., Bavister, B.D. \& First, N.L. (1983) Factors affecting successful in vitro fertilization of bovine follicular oocytes. Biology of Reproduction 28, 717-725.

Barnes, F.L. (1988) Characterization of the onset of embryonic control and early development in bovine embryos. PhD Thesis, University of Madison, Wisconsin.

Betteridge, K.J. \& Fléchon, J.E. (1988) The anatomy and physiology of pre-attachment bovine embryos. Theriogenology 29, 155-187.

Bissell, M.J., Ram, T.G. \& Chen, L. (1988) Regulation of gene expression by extracellular matrix in higher eukaryotes. In Gene Expression and Regulation: The Legacy of Luigi Gorini, pp. 279-287. Eds M. J. Bissel, G. Deho, G. Sironi \& T. Torrani. Elsevier Science Publishers, New York.

Bornslaeger, E.A. \& Schultz, R.M. (1985) Adenylate cyclase activity in zona-free mouse oocytes. Experimental Cell Research 156, 277-280.

Camous, S., Heyman, Y., Meziou, W. \& Menezo, Y. (1984) Cleavage beyond the block stage and survival after transfer of early bovine embryos cultured with trophoblastic vesicles. Journal of Reproduction and Fertility 72, 479-485.

Cardarelli, P. \& Pierschbacher, M. (1987) Identification of fibronectin receptors on T lymphocytes. Journal of Cell Biology 105, 499-506.

Edelman, G.M. (1988) Topobiology: An Introduction to Molecular Embryology. Basic Books, Inc., New York.

Eyestone, W.H. \& First, N.L. (1989) Co-culture of early cattle embryos to the blastocyst stage with oviductal tissue or conditioned medium. Journal of Reproduction and Fertility 85, 715-720.

Frei, R.E., Schultz, G.A. \& Church, R.B. (1989) Qualitative and quantitative changes in protein synthesis occur at the 8-16-cell stage of embryogenesis in the cow. Journal of Reproduction and' Fertility 86, 637-641.

Gospodarowicz, D., Cohen, D. \& Fuji, D.K. (1982) Regulation of cell growth by the basal lamina and plasma factors: relevance to embryonic control of cell proliferation and differentiation. In Conferences on Cell Poliferation Vol. 9, Growth of Cells in Hormonally Defined Media, pp. 13I-143. Eds G. H. Sato, A. B. Pardee \& D. A. Sirbasku. Cold Spring Harbor, New York.

Hamilton, W.J. \& Laing, J.A. (1946) Development of the egg of the cow up to the stage of blastocyst formation. Journal of Anatomy 80, 194--204.

Hnatowich, D.J., Virzi, F. \& Rusckowski, M. (1987) Investigations of avidin and biotin for imaging applications. Journal of Nuclear Medicine 28, 1294-1302.

Kapur, R.P. \& Johnson, L.V. (1986) Selective sequestration of an oviductal fluid glycoprotein in the perivitelline space of mouse oocytes and embryos. Journal of Experimental Zoology 238, 249-260.

Lash, J.W., Linask, K.K. \& Yamada, K.M. (1987) Synthetic peptides that mimic the adhesive recognition signal of fibronectin: differential effects on cell-cell and cell-substratum adhesion in embryonic chick cells. Developmental Biology 123, 411-420.

Lee, G., Hynes, R. \& Kirschner, M. (1984) Temporal and spatial regulation of fibronectin in early Xenopus development. Cell 36, 729-740.

Leese, H.J. (1988) The formation and function of oviductal fluid. Journal of Reproduction and Fertility 82, 843-856.

McDonald, J.A. (1988) Extracellular matrix assembly. Annual Reviews of Cell Biology 4, 183-207.

Menezo, Y., Testart, J. \& Perrone, D. (1984) Serum is not necessary in human in vitro fertilization, early embryo culture, and transfer. Fertility and Sterility 42, 750-755.

Parrish, J.J., Susko-Parrish, J.L. \& First, N.L. (1985) Effect of heparin and chondroitin sulfate on the acrosome reaction and fertility of bovine sperm in vitro. Theriogeneology 24, 537-549.

Parrish, J.J., Susko-Parrish, J., Winer, M.A. \& First, N.L. (1988) Capacitation of bovine sperm by heparin. Biology of Reproduction 38, 1171-1180.

Pierschbacher, M. \& Ruoslahti, E. (1984a) Cell attachment activity of fibronectin can be duplicated by small synthetic fragments of the molecule. Nature $309,30-33$.

Pierschbacher, M. \& Ruoslahti, E. (1984b) Variants of the cell recognition site of fibronectin that retain attachment promoting activity. Proceedings of the National Academy of Sciences, USA 81, 5985-5988.

Quaroni, A. (1985) Crypt cell development in newborn rat small intestine. Journal of Cell Biology 100, $1601-1610$.

Ruoslahti, E., Hayman, E.G., Pierschbacher, M.D. \& Engvall, E.F. (1982) Fibronectin: purification, immunological properties, and biological activities. Methods in Enzymology 82, 803-830.

Thibault, C. (1966) Le culture in vitro de l'oeuf de vache. Annales de Biologie Animale, Biochimie, Biophysique 6, 159-164.

Vestaweber, D., Gossler, A., Boller, K. \& Kemler, R. (1987) Expression and distribution of cell adhesion molecule uvomorulin in mouse preimplantation embryos. Developmental Biology 124, 451-456. 
Wassarman, P.M. (1990) Profile of the mammalian sperm receptor. Development 108, 1-17.

Watt, F.M. (1986) The extracellular matrix and cell shape. Trends in Biochemical Sciences 11, 482-485.

Wilton, L.J. \& Trounson, A.D. (1989) Biopsy of preimplantation mouse embryos. Development of micromanipulated embryos and proliferation of single blastomeres in vitro. Biology of Reproduction 40, 145-152.

Yamada, K.M., Kennedy, D.W. \& Hayashi, M. (1982) Fibronectin in cell adhesion, differentiation, and growth. In Conferences on Cell Proliferation Vol. 9, Growth of Cells in Hormonally Defined Media. Eds G. H. Sato, A. B. Pardee \& D. A. Sirbasku. Cold Spring Harbor, New York.

Yokkaichiya, T., Hoshiai, H., Uehara, S. \& Yajima, A. (1988) Fibronectin localization in the mouse embryo from the two cell stage to the morula stage. Tohoku Journal of Experimental Medicine 154, 95-100.

Received 20 August 1991 